\title{
Recent discoveries of corticolous Licea species from the British Isles with descriptions of two new species
}

\author{
DAVID W. MITCHELL and ROLAND McHUGH
}

\begin{abstract}
MITCHELL, D.W. \& McHUGH, R. 2000: Recent discoveries of corticolous Licea species from the British Isles with descriptions of two new species. - Karstenia 40: 103-109. Helsinki. ISSN 0453-3402.

The authors have each specialised in the moist-chamber culture of bark sampled from living trees and have recently initiated a special investigation of the bark of Sambucus nigra. The original description of Licea microscopica D.W. Mitch. is amended in the light of numerous recent collections and Licea sambucina D.W. Mitch. nov. spec. is described. Both taxa are abundant in many localities in S.E. England on alga-covered bark of Sambucus nigra L. Interesting collections of other spp. of Licea are reported, including L. scintillans McHugh \& D.W. Mitch. nov. spec. which has previously been confused with $L$. iridis Ing \& McHugh. Characters used to distinguish between aberrant forms of L. operculata (Wingate) G.W. Martin and L. scyphoides H.W. Keller \& T.E. Brooks are outlined.
\end{abstract}

Key words: Algae, corticolous, Licea microscopica, Licea operculata, Licea sambucina, Licea scintillans, Licea scyphoides, Myxomycetes, Sambucus nigra

David W. Mitchell, Walton Cottage, Upper Hartfield, Sussex, TN7 4AN, England. Email: SlimeLord@myxo.freeserve.co.uk

Roland McHugh, Dublin Institute of Technology, Cathal Brugha Street, Dublin 1, Ireland. E-mail: Roland.mchugh@dit.ie

\section{Introduction}

After an interval of more than 20 years since the discovery in Wales of the myxomycete Licea microscopica by D.W. Mitchell (1978, 1980), the species was re-found in Sussex, England, in a moist-chamber culture of alga-covered bark of living Elder stems (Sambucus nigra L.). The bark of this small tree has apparently only rarely been investigated. A single taxon, Licea floriformis T.N. Lakh. \& R.K. Chopra var. aureospora M. Willemse \& Nann.-Bremek. (1994), has been described from this habitat in the Netherlands but has not been found in this present study.

At the end of 1998, we decided to undertake a joint study of the myxomycete biota of Elder. The bark has a corky texture, particularly in younger stems, and possesses a very high water-holding capacity which is conducive to the proliferation of algae. These investigations have resulted in the discovery of other Licea spp., two of which have proven to represent new taxa. Numerous bark cultures of Elder by the two authors have shown that L. microscopica is strongly associated with epiphytic green algae and is, in fact, an abundant corticolous species in this particular microhabitat. The distinguishing character of this taxon is its habit of developing immersed in algae, leaving a gelatinous sac after spore-dispersal. As a result of our being able to observe the developmental stages of this species in numerous moist chambers from south-east England and Ireland, together with many field collections of mature material, the original description is amended in this paper. 


\section{Materials and methods}

In 1998, DWM harvested a single sporocarp of an unidentified Licea from a moist-chamber culture of Elder bark collected at Devil's Dyke, West Sussex which, like $L$. microscopica, was also associated with algae. At first, the sporocarp was mistaken for a pellet of insect frasse but, by applying gentle pressure with forceps to the surface of the object, a transparent sac of red-brown spores was ejected from a gelatinous envelope. Observation by compound microscope showed that this was indeed a species of Licea whose spores matched those of L. inconspicua H.W. Keller \& T.E. Brooks (1977) but, unlike that species, its peridium was seen to be divided into distinct platelets with tuberculate margins. Subsequent studies have resulted in collections of this taxon on Elder bark from over one hundred sites in south-east England. The development of this myxomycete was easily observed as a result of the ease with which its conspicuous orange protoplasmodia could be detected under the lens and collected in the field for subsequent culture. The taxon is described below as Licea sambucina.

In Ireland, RM found both of the above spp. on living Sambucus nigra in culture and additionally L. microscopica on alga-covered bark of Ulex europaea. In July 1999, DWM collected bark samples from living trees in the Great Smoky Mountains National Park, which also yielded L. sambucina in culture. Mrs. D. Wrigley de Basanta, who has processed numerous moist chambers of the bark of Quercus ilex from Spain, harvested $L$. sambucina in a culture from Madrid. This material was accompanied by L. nannengae (Pando \& Lado 1988), a species known only from Spain and Ohio (Keller \& Braun 1999) until it appeared on a culture of Elder bark from Co. Offaly, Ireland. Licea nannengae is a minute species with a shiny peridium that is not divided into platelets and has spores with a prominent germinative pore. Similar attributes occur in another new corticolous species which we describe below as Licea scintillans.

In this paper, terminology used for myxomycete structures follows that of Lado and Pando (1997) and abbreviations used for author citations follow the recommendations made by Brummitt and Powell (1992).

All figures that are included in this paper are taken from Mitchell (2000). Photographs were made using Olympus $35 \mathrm{~mm}$ SLR cameras fitted to an Olympus FHT compound microscope and Wessex WZ stereo zoom microscope.

\section{Descriptions and new species}

Licea microscopica D.W. Mitch. The description is here amended to include collections of mature field material and further specimens cultured in moist-chambers of alga-covered bark of both living and dead stems of Sambucus nigra.

Protoplasmodium orange-yellow. Sporocarps scattered, sessile, subglobose or elongate, coppery to deep reddish-brown while immature, grey in the mature state, $50-200 \mu$ m diameter, sometimes elongated and occasionally up to $500 \mu \mathrm{m}$ long, of- ten deeply immersed in an algal layer so that only the upper peridium is visible. Peridium pale yellowish-brown by transmitted light, minutely punctate inside. Dehiscence either irregular or circumscissile around the region where the peridium meets the surface of the surrounding algal layer and then forming a raised lid. Spore-mass golden brown. Spores, by transmitted light, at first pale yellow-brown but becoming red-brown at maturity, smooth, globose and with a pale area showing as $40 \%$ or more of the circumference in optical section, (13-)15-17 $\mu$ m diameter.

Seasonal occurrence: Throughout the year.

Distribution: Wales: Glamorganshire. England: East and West Sussex, Surrey, East and West Kent (mostly on Sambucus nigra, but occasionally on alga-covered bark of other trees). Ireland: Co. Meath, Co. Wexford, Co. Kildare, West Cork, South Kerry, Co. Wicklow. USA: Tennessee (on bark of living Liriodendron tulipifera in moist-chamber).

The present known distribution is extended from that given by Ing (1999) and it is highly probable that this abundant species occurs wherever Sambucus nigra is found. Photomicrographs of this species have recently been published in colour (Mitchell 2000).

A sessile, operculate Licea with spores of a similar colour to those of L. microscopica has recently been found by DWM on bark collected from the Great Smoky Mountains National Park, USA and from Spain. These specimens resemble L. parasitica (Zukal) G.W. Martin in all respects except for the golden brown colour of the sporemass, the red-brown colour of their spores by transmitted light and their red-brown sporocarps. This material was not apparently associated with algae and may represent a new variety of L. parasitica.

Licea sambucina D.W. Mitch. nov. spec. - Figs. 1-6

Protoplasmodia et sclerotia aurantiaca. Sporocarpi brunnei, hebetes aut nitidi, sessiles, fere elongati et $0.10 \times 0.25 \mathrm{~mm}$, aut rotundi aut trianguli desuper, tunc 0.1-0.2(-0.3) mm lati. Peridium membranaceum, luce transmissa aut pellucidum et hyalinum aut pallidissime fulvum, leve, intra minute punctatum et funditus cum reticulo hebete macularum diametri prope aequalis sporis insignis, in gelatino tenaci extrusi faciliter includi, sparsi depositae rejecti capax. 
Peridium in bracteae cujus margines tuberculi c. 1-4 um lati irregulariter dispersi porta divisi. Sporocarpi elongata ex scissura longitudinali scindens. Sporae rufobrunneae pallidae, luce transmissa rufobrunneae pallidae minute et aequabiliter verrucatae, sine foramine germinativo.

Type: England. East Sussex (VC 14), Lye Green, from moist-chamber culture of bark taken

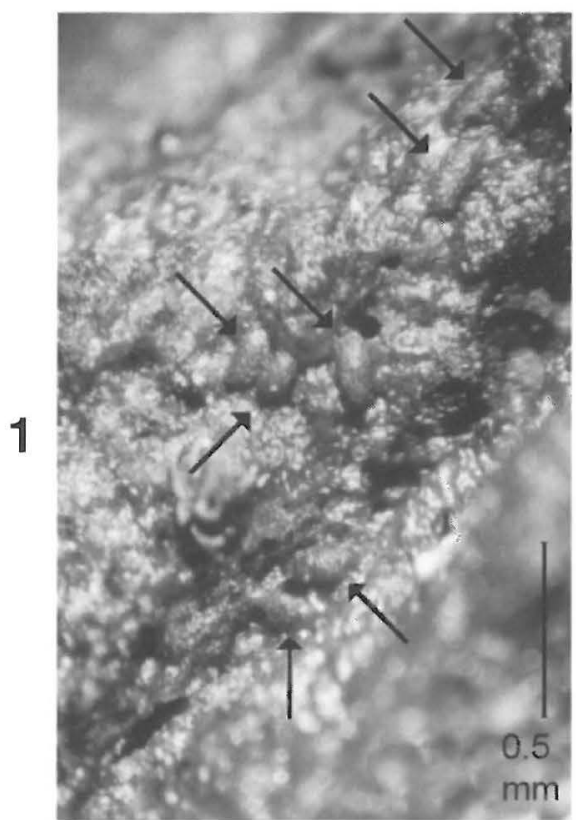

from living Sambucus nigra, National Grid Reference TQ509343, 9.II.1999 D.W.Mitchell 5640 (holotype: private herbarium of D.W. Mitchell; isotypes: $\mathrm{K}, \mathrm{BPI}$ ).

Protoplasmodia and sclerotia orange. Sporocarps dull or shiny brown, sessile, mostly elongated and $0.10 \times 0.25 \mathrm{~mm}$ or circular or triangular from above and then c. 0.1-0.2(-0.3) mm diam. (Fig. 1). Peridium membranous, transparent and

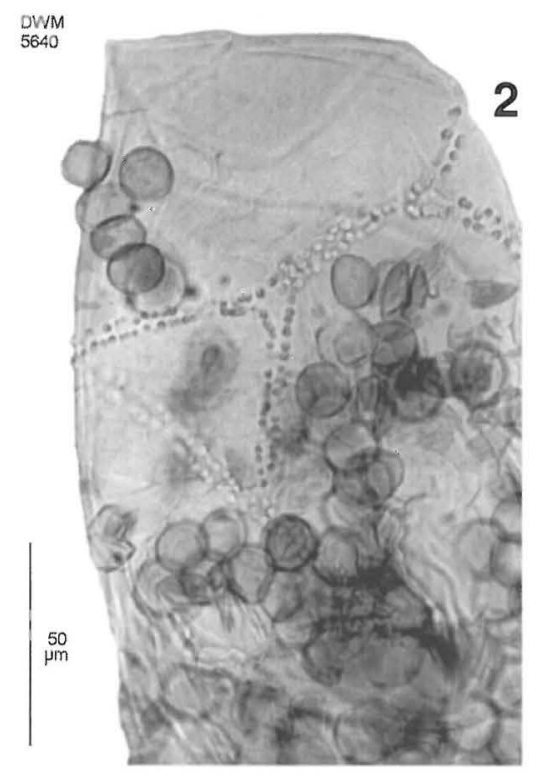

Figs. 1-4. Licea sambucina. - Fig. 1. Type specimen in situ on bark of living Sambucus nigra. - Fig. 2. Type specimen - peridium with lines of tubercles. - Fig. 3. Type specimen - no dehiscence line is visible between the double row of tubercles. - Fig. 4. Specimen from Tennessee, showing small peridial tubercles along edges of peridial fractures.
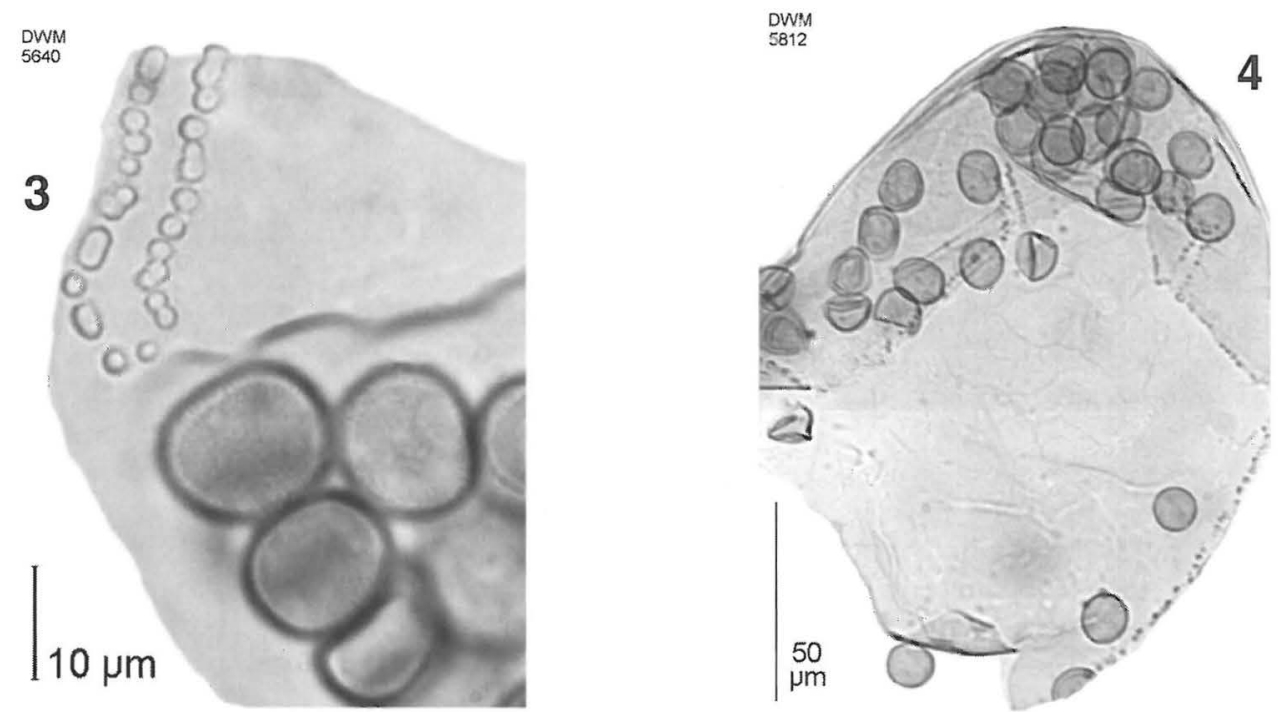

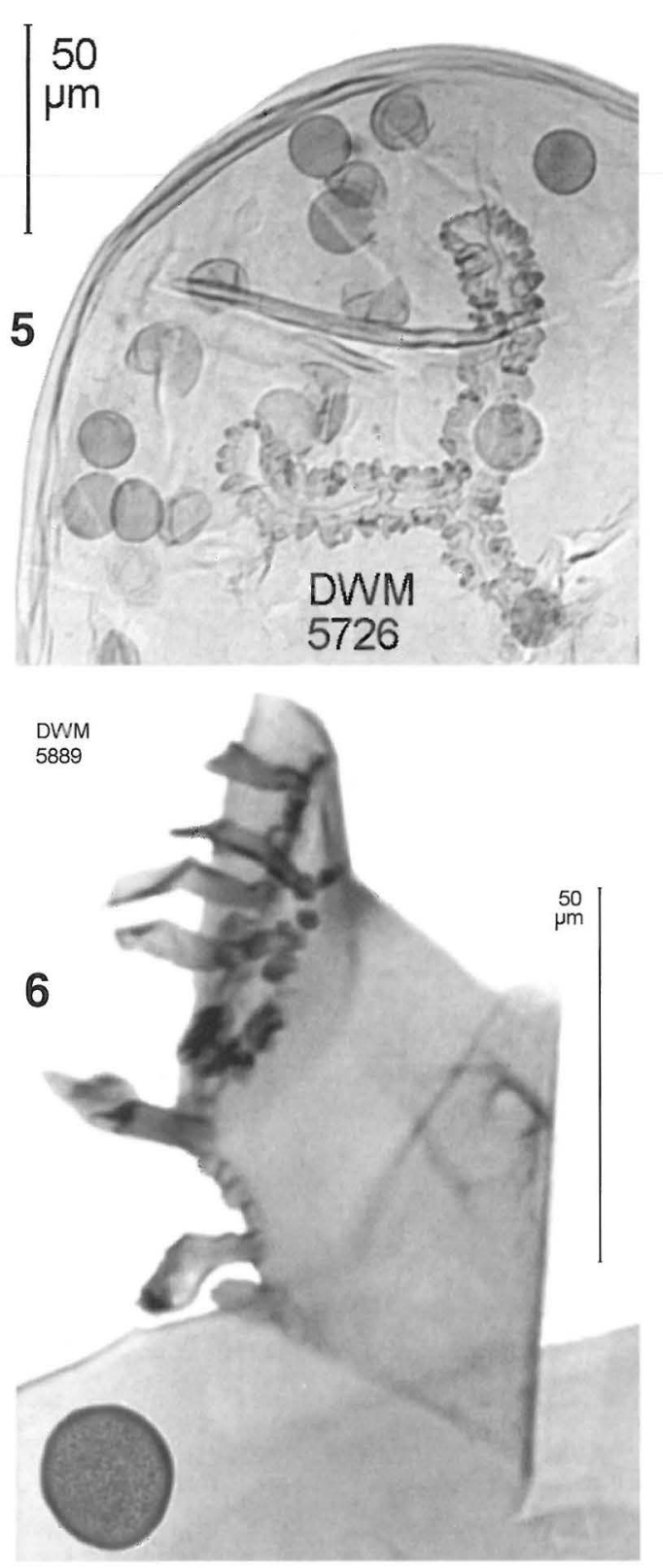

Figs. 5-6. Licea sambucina. - Fig. 5. Specimen from Madrid, Sapin, with fused tubercles. Fig. 6. Elongated tubercles of a specimen from Tennessee.

hyaline or very pale yellow-brown by transmitted light, smooth, minutely punctate inside and marked basally with a faint reticulum of polygonal ridges that are about the same diameter as that of the spores, enclosed in a tough gel containing sparse refuse deposits from which the sporotheca is readily extruded. Peridium divided into platelets with their margins marked with irregularly distributed, hyaline tubercles c. $1-4 \mu \mathrm{m}$ diam. (Figs. 2-6 illustrate known variations in this character). Dehiscence by means of lobes, often appearing as a longitudinal slit in elongated sporocarps. Spore-mass pale red-brown. Spores, by transmitted light, pale red-brown, 13$14(-15) \mu \mathrm{m}$ diameter, minutely and evenly verruculose, without a germinative pore (Fig. 3).

Collected from more than one hundred sites in both the mature state and from moist-chamber culture on bark of living Sambucus nigra L. in the British Isles, from moist-chamber culture of bark taken from living Sambucus pubens Michaux in North Carolina and as mature sporocarps on Prunus serotina Ehrhart from Tennessee. No other species in the genus Licea has the combination of a hyaline peridium and platelets edged with tubercles. This distinctive species shows certain similarities to $L$. inconspicua but that species is reported with a triple peridium and sporocarps which are subglobose to hemispheric. Material of L. inconspicua, sent to DWM by Professor Keller, has been closely investigated by the first author and neither platelets nor lines of tubercles were evident in any of these specimens.

Etymology: From Sambucus, the Latin generic name of its primary phorophyte.

Seasonal occurrence: Throughout the year.

Distribution: England: East and West Sussex, Surrey, East and West Kent. Ireland: Co. Wexford. Spain: Madrid. USA: Great Smoky Mountains National Park in North Carolina and Tennessee.

Licea scintillans McHugh \& D.W. Mitch. nov. spec. - Fig. 7

Sporocarpi sparsi, aut brevistipitati aut sessiles, 0.18-0.22 mm lati, valde iridiscentes. Peridium simplex, membraceum, hyalinum, leve, cum floccis materiae rejectae ad sporothecas adherentes, quando siccus rugosus. Sporae rufobrunneae, luce transmissa ochraceae pallidae, 10-10.5 um lati, laeves, cum foramine germinativo manifesto $25-33 \%$ ambitae instructae.

Type: Ireland. Co. Kildare ( VC H19), Hill of Allen, on bark of Quercus petraea in moistchamber culture, Irish National Grid Reference N 7521, 22.I.1981 R. McHugh 303 (holotype: DBN).

Sporocarps scattered, short-stipitate or sessile. Sporotheca globose, $0.18-0.22 \mathrm{~mm}$ diam., 
strongly iridescent. Peridium single, membranous, hyaline, smooth, with scattered fragments of refuse matter adhering to the surface, wrinkled when dry. Spore-mass reddish-brown. Spores, by transmitted light, pale ochraceous, 10-10.5 $\mu \mathrm{m}$ diameter, smooth, thick-walled and with a conspicuous germinative pore occupying 25$33 \%$ of the circumference.

Collected from moist-chamber culture on the bark of living Quercus petraea (Mattuschka) Liebl. in Ireland and Ulmus in Sussex, England. This new species had been previously confused with L. iridis Ing \& McHugh (1988) which differs in its sub-stipitate sporocarps and coarsely verrucose spores.

Etymology: From the Latin, scintillatio (sparkling) with reference to the highly iridescent peridium.

Distribution: Ireland: Co. Kildare. England: DWM4749, Friston Forest, near Westdean, East Sussex.

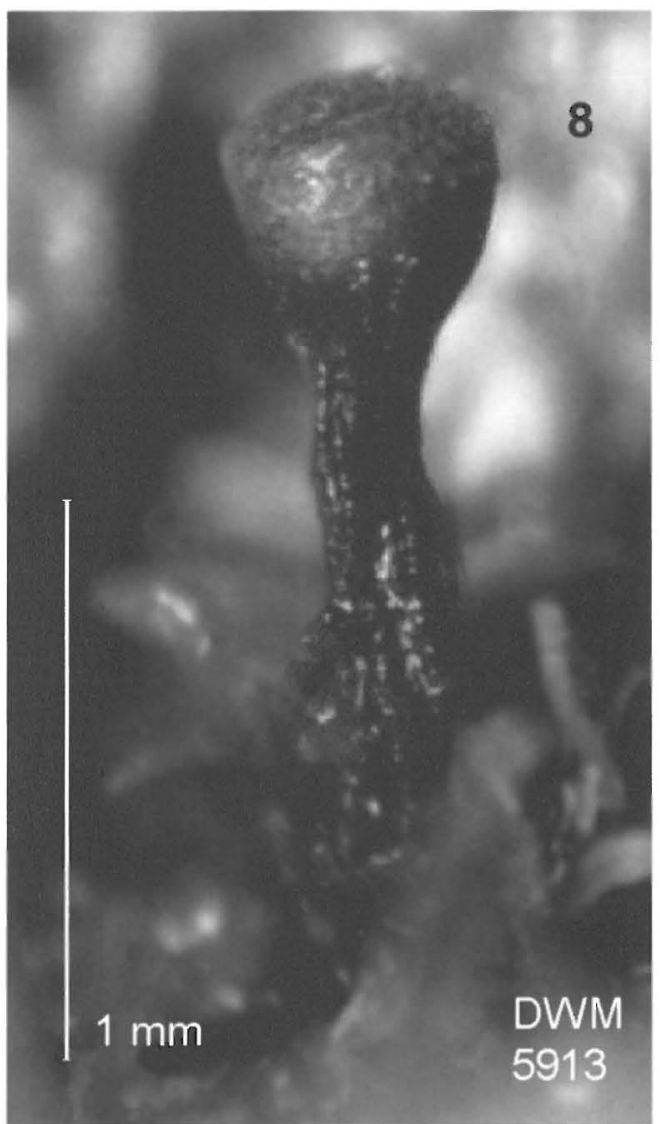

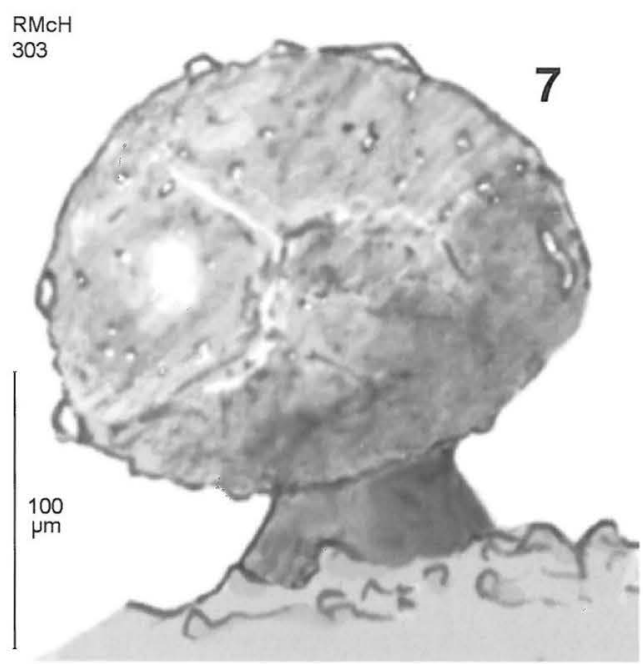

Fig. 7. Licea scintillans. Line drawing of a sporocarp of the type specimen.

Figs. 8-9. Licea scyphoides on bark of living Sambucus nigra, Sussex, England. - Fig. 8. Sporocarp in situ. Fig. 9. Mounted specimen showing the peridium closed off from the stalk and the mottled appearance of the upper half of the peridium.

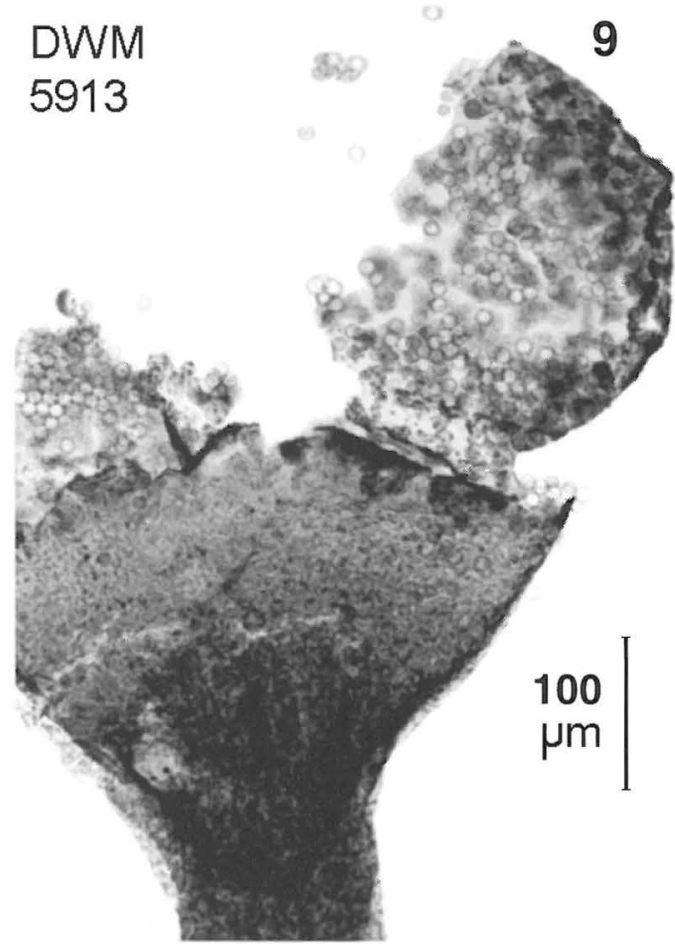


New records for Ireland cultured on bark of living Sambucus nigra

Licea nannengae Pando \& Lado: The first record from the British Isles is reported from Clara, Co. Offaly, (VC H18), Irish National Grid Reference N 255320, 1.II.1999 R. McHugh 582.

L. pedicellata (H.C. Gilbert) H.C. Gilbert: The first record for Ireland:. On bark collected from the bank of the Grand Canal, near Straffan, Co. Kildare ( VC H19), Irish National Grid Reference N 9326, 25.IV.1999 R. McHugh 589.

\section{Variation in Licea operculata (Wingate) G.W. Martin and $L$. scyphoides H.W. Keller \& T.E. Brooks}

Licea operculata is a species very prone to variation. Typically its sporotheca has a well-developed operculum and is raised on a long, narrow stalk. However, particularly in moist chamber, sporocarps sometimes develop without an operculum and may be short-stalked (Fig. 12). An inoperculate variant, described as L. capitata Ing \& McHugh (Ing 1982) is now regarded as a synonym of $L$. operculata (Ing 1999). This form has occurred in wetter regions of the British Isles and in moist chamber bark cultures where epiphytic mosses and liverworts retain excessive moisture for the normal development of the myxomycete. On mounting, the sporotheca usually splits at the apex, due to pressure of the coverslip (Fig.12).

Confusion between short-stalked inoperculate forms of Licea operculata and L. scyphoides is possible. In moist chamber culture, L. scyphoides is commonly encountered on the bark of Elder where its distinctive equatorial dehiscence is often not apparent. This species is typically $1 \mathrm{~mm}$ in total height and has inoperculate spo-

Figs. 10-11. Licea scyphoides. Fig. 10. Detail of the upper peridium showing areas of refuse deposits with clear bands between. - Fig. 11. Detail of stalk apex and base of the sporotheca.
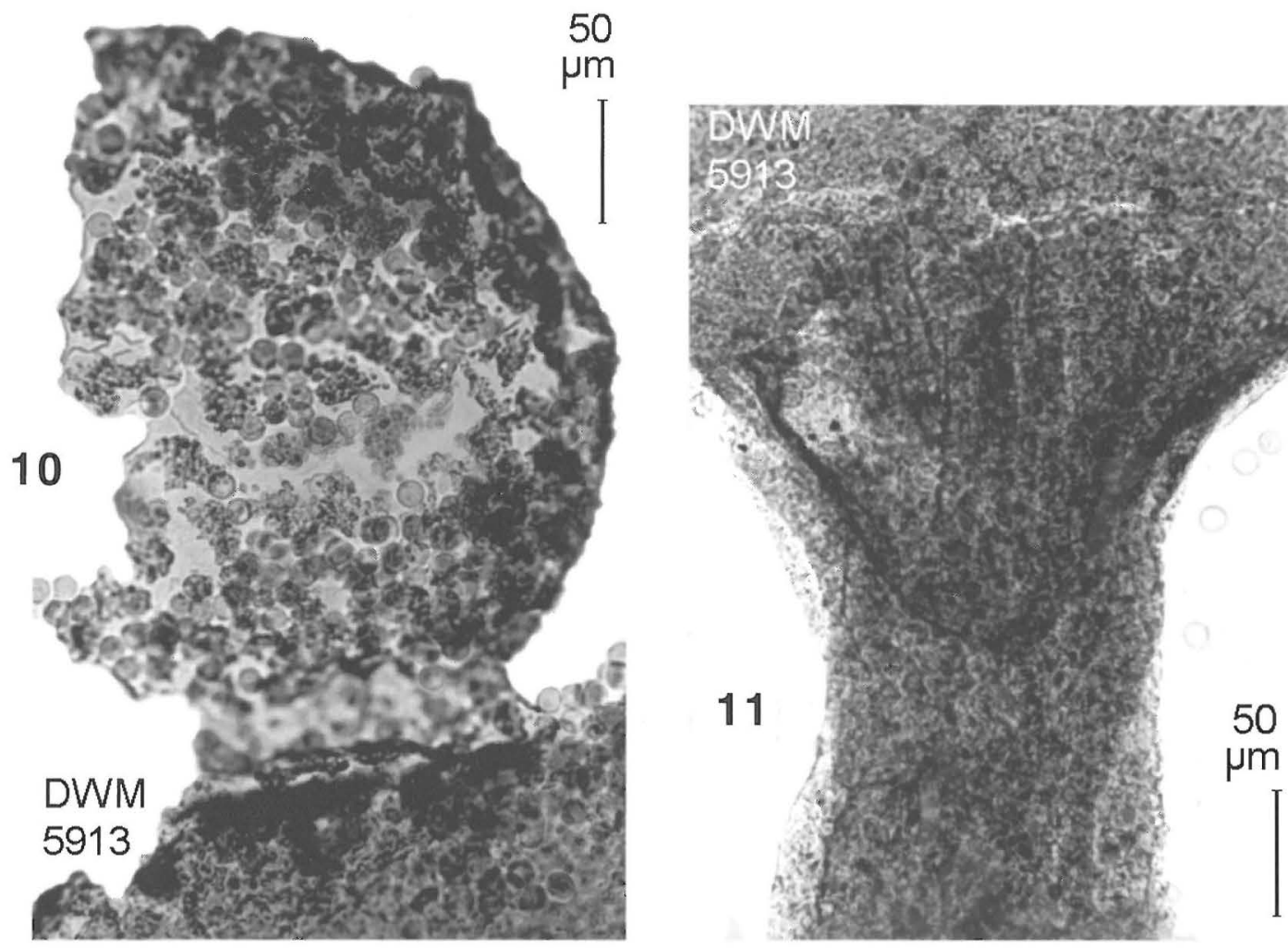
rothecae which are bright orange when unripe and raised on a stout stalk reaching up to about $50 \%$ of the total height. The sporotheca becomes dark brown at maturity and the peridium often acquires a wrinkled texture, whilst the stalk displays a series of longitudinal ridges. An additional character to assist the identification of this species is the presence of a clear separation between the sporotheca and the stalk (Figs. 9, 11). Accumulations of refuse matter often give rise to a mottled appearance of the upper peridium when viewed by transmitted light (Fig. 10) whereas, in L. operculata, the upper peridium (or the operculum, if present) is free of such deposits (Fig. 12).

Fig. 12. The "capitata" form of Licea operculata showing the apical splitting of the sporotheca.

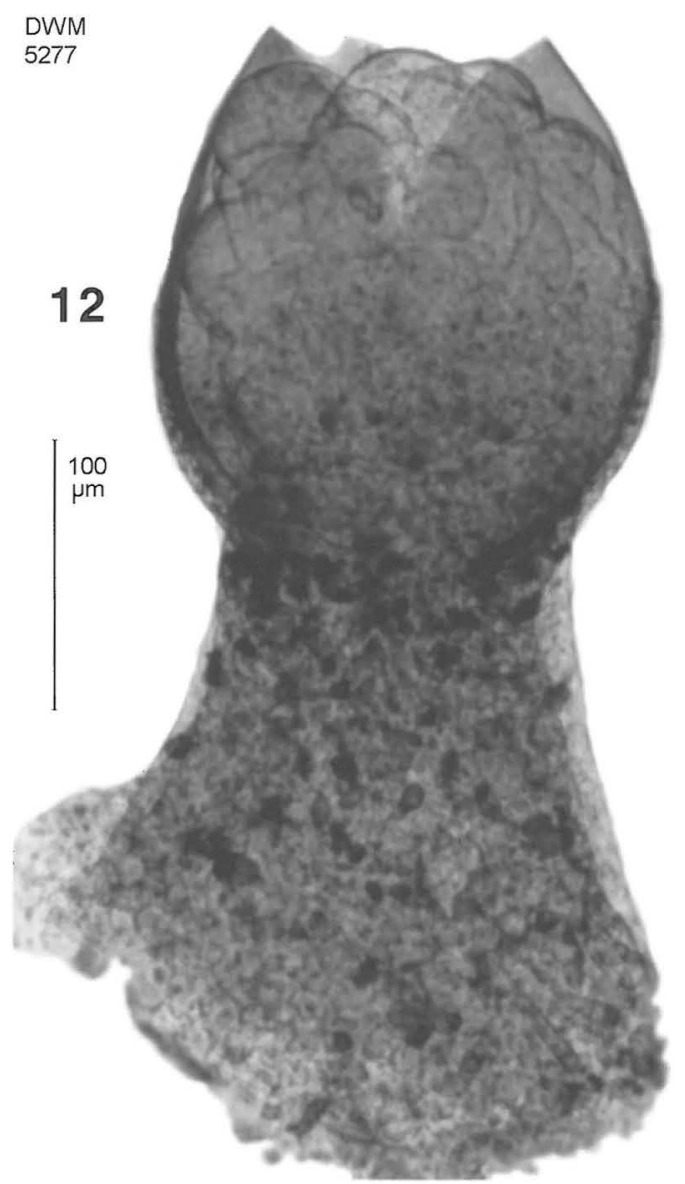

Acknowledgements: We wish to thank Professor John Dillon of Trinity College, Dublin for assistance with the preparation of the Latin diagnoses. The first author is indebted to Professor Harold Keller of Central Missouri State University, Warrensburg, for his informed discussion on the status of Licea sambucina and advice and encouragement over many years of correspondence. Field work in the Great Smoky Mountains National Park by DWM was supported in part by a grant from Discover Life in America.

\section{References}

Brummitt, R.K. \& Powell, C.E. (eds.) 1992: Authors of plant names. - Royal Botanic Gardens, Kew. 732 pp. Ing, B. 1982: Notes on Myxomycetes III. - Trans. Br. Myc. Soc. 78(3): 439-446.

Ing, B. 1999: The myxomycetes of Britain and Ireland. - Richmond Publishing Co. Ltd. 374 pp.

Ing, B. \& McHugh, R. 1988: A revision of Irish myxomycetes. - Proc. Royal Irish Academy 88 B: 7-117.

Keller, H.W. \& Braun, K.L. 1999: Myxomycetes of Ohio: their systematics, biology and use in teaching. Ohio Biol. Survey 13(2).

Keller, H.W. \& Brooks, T.E. 1977: Corticolous myxomycetes VII. Contribution toward a monograph of Licea, five new species. - Mycologia 69: 667-684.

Lado, C. \& Pando, F. 1997: Myxomycetes, I. Ceratiomyxales, Echinosteliales, Liceales, Trichiales. - Flora Mycologica Iberica, 2. Real Jardín Botánico, Madrid \& J. Cramer. 324 pp.

Mitchell, D.W. 1978: A key to the corticolous myxomycetes. Part 1. - Bull. Brit. Mycol. Soc. 12: 18-42.

Mitchell, D.W. 1980: A key to the corticolous myxomycetes. - Brit. Mycol. Soc. 63 pp.

Mitchell, D.W. 2000: Myxomycetes 2000. - CDRom of keys and an inventory of world myxomycetes with descriptions, monograph references and illustrations. - Private publication by the author.

Pando, F. \& Lado, C. 1988: Two new species of corticolous myxomycetes from Spain. - Mycotaxon 31: 299-303.

Willemse, M. \& Nannenga-Bremekamp, N.E. 1994: Licea floriformis var. aureospora, a new myxomycete from the Netherlands. - Proc. Koninkl. Nederl. Akad. van Wetenschappen C 97: 137-140.

Wrigley de Basanta, D. 1998: Myxomycetes from the bark of the evergreen oak Quercus ilex. - Anales Jard. Bot. Madrid 56: 3-14.

Yamamoto, Y. 1998: The myxomycete biota of Japan. - Toyo Shorin Publishing Co. Ltd., Tokyo. 700 pp. 